\title{
Identifying of Groundwater Pollution in Lower Code Watershed, Yogyakarta
}

\author{
Muryanto $^{1 *}$, Suntoro ${ }^{1}$, Totok Gunawan ${ }^{2}$, Prabang Setyono ${ }^{1}$ \\ ${ }^{1}$ Departement of Environmental Science, Sebelas Maret University, Jalan Ir. Sutami 36 A, Surakarta, 57126, Indonesia \\ ${ }^{2}$ Departement of Geography, Gadjah Mada University, Bulaksumur, Caturtunggal, Depok, Sleman, Yogyakarta 55281, Indonesia \\ *Email: muryanto_65@yahoo.com
}

\begin{abstract}
Muryanto, Suntoro, Gunawan T, Setyono P. 2017. Identifying Of Groundwater Pollution in Lower Code Watershed, Yogyakarta. Proc Internat Conf Sci Engin 1: 23-26. The water source of the people residing in Code Watershed is currently accessed from water wells, which are privately owned by most of the house. The urban area in the watershed is highly populated and its waste is disposed of into the ground, which contaminates groundwater. Therefore, an urban area located in a higher topography poses threats to the groundwater quality downstream. The research found that the groundwater in the lower part of Code Watershed was polluted because it received the waste discharge from the city upstream and, at the same time, had to deal with the existing pollution in it.
\end{abstract}

Keywords: Household waste, groundwater, groundwater pollution

\section{INTRODUCTION}

Water is very important in human life. Human and other living beings are unable to live without it. The groundwater used by the local people is polluted by domestic wastes that are discarded into the ground. Groundwater is used to fulfill daily water needs, namely, for cooking, bathing, washing, etc. The water resource of the people living in Code Watershed is mostly acquired using water wells, which are privately owned by most of the houses in the watershed. When the urban area located in a higher topography in a watershed is densely populated and its waste is disposed of into the ground, it potentially contaminates the groundwater downstream.

\section{MATERIALS AND METHODS}

\section{Research Object}

The research object is groundwater in Code Watershed. The groundwater was sampled two times from areas outside the city and two times from areas close to Opak River (the lower stream of Code River). The volume of each sample was 1 liter, stored in a bottle that was initially cleaned and rinsed with sample water. The sample has to fill up the bottle, then the bottle has to be properly closed in order to avoid contact with air. For iron $(\mathrm{Fe})$ content analysis, the water sample has to meet the following requisites, namely: (1) it has to fill up the 100-ml sample bottle; (2) there has to be no air bubble inside the bottle; (3) it has to be added with a preservative, i.e. Chloride Acid; and (4) it has to be airtight. In order to analyze biological parameters, the sample bottles were sterilized and then dried. The preservation of water samples for biological parameters involves a cold condition and an isothermic box filled with ice for sample transportation. A mistake in water sampling procedure for biological parameter analysis is fatal because the results of the laboratory analysis will be significantly different from when the water sampling follows the procedure correctly. Therefore, a comprehension and a knowledge of correct water sampling procedure are necessary.

\section{Data Acquisition}

The data acquisition technique in this research was field observation, which aimed to monitor the field condition directly since the beginning of the survey until the implementation of the research. The urban area, along with the downstream area of the city and the upstream area of Opak River (the lower stream of Code Watershed) were observed during the research. The data used in this research were as follows:

Primary Data: The research data were obtained directly from the results of laboratory-scale research. The water samples obtained from the predefined points were analyzed in the laboratory. These served as the primary data namely, physical, chemical, and biological characteristics of water quality.

\section{Research Materials}

The research used the following materials: groundwater samples in Code Watershed and $\mathrm{HCl} 1 \mathrm{~N}$.

\section{Research Equipment}

The equipment used in this research was as follows: 4 pieces of 1-liter sample bottles, 4 pieces of sample bottles for bacteria analysis, 4 pieces of 100-ml sample bottles for iron content analysis, 1 piece of water dipper for collecting water sample, 1 piece of water sampler, 1 piece of EC meter for measuring electrical conductivity in the field, stationary, a set of computer for processing digital data and writing thesis, Global Positioning System (GPS) for pinpointing the location of water 
samples in the field, and the Indonesian Topographic Map (RBI) in a scale of 1: 25,000.

\section{Research Steps}

\section{Preparation}

This step included preliminary study, research permit application, and the procurement of research tools, materials, and the other necessary instruments.

2. Water Sampling

This step included groundwater and spring water sampling. Spring and groundwater were sampled using water dipper and water sampler and then poured into the bottles that were firstly rinsed with sample water. In addition, this step included the analysis of groundwater and spring water samples in the Laboratory of Hydrology and Water Quality, Faculty of Geography, Gadjah Mada University.

3. Analyzed Parameters

The parameter analysis is based on Governor Regulation no. 20/2008 on Water Quality Standards in Yogyakarta Special Region, including standard of physics, chemistry and biology parameters. Physical parameters analyzed in this research are temperature, TSS, TDS, turbidity, and electrical conductivity. The chemical parameters consist of $\mathrm{pH}$, dissolved oxygen (DO), BOD, COD, free ammonia (NH3 -N), nitrate (N03-), nitrite (N02-), sulphate (SO4-2), chloride $(\mathrm{Cl}-)$, and total iron $(\mathrm{Fe})$. The biological parameter is the total coliform.

\section{Laboratory Analysis}

The next step was to analyze the water samples in the laboratory, which in this case was the Laboratory of Hydrology and Water Quality, Faculty of Geography UGM. The parameters analyzed in the laboratory were as follows: turbidity (measured using turbidimeter), temperature (using mercury thermometer), $\mathrm{pH}$ (using $\mathrm{pH}$ meter), electrical conductivity (using EC meter), Dissolved Oxygen and BOD (measured using Winkler bottle and volumetric method), COD (using permanganate method), free ammonia $\left(\mathrm{NH}_{3}-\mathrm{N}\right)$, nitrate $\left(\mathrm{NO}_{3}{ }^{-}\right)$, nitrite $\left(\mathrm{NO}_{2}{ }^{-}\right)$, sulfate $\left(\mathrm{SO}_{4}^{-2}\right)$, and total iron $(\mathrm{Fe})$ (using spectrophotometer), chloride (using volumetrictitration method), and total coliform (using multiple-tube fermentation with three tubes).

\section{Data Analysis}

The research data analysis included:

a. Analysis on physical parameters (i.e., temperature, TSS, TDS, turbidity, and electrical conductivity), chemical parameters (i.e., pH, Dissolved Oxygen (DO), BOD, COD, free ammonia $\left(\mathrm{NH}_{3}-\mathrm{N}\right)$, nitrate $\left(\mathrm{NO}_{3}{ }^{-}\right)$, nitrite $\left(\mathrm{NO}_{2}^{-}\right)$, sulfate $\left(\mathrm{SO}_{4}^{-2}\right)$, chloride $\left(\mathrm{Cl}^{-}\right)$, and total iron $(\mathrm{Fe}))$, and biological parameters (i.e., total coliform).

b. The determination of environmental quality status.

The water quality status was determined in Water Quality Monitoring Activity using one of the proposed methods in the Decree of the Minister of Environment No. KEP-115/MENLH/2003, i.e., Pollution Index (PI) method. This method was used to determine the pollution level relative to the allowed presence of each parameter in the water. The concept of Pollution Index (PI) is different fromthat of the Water Quality Index. The former index is meant for determining the proper use of an entire water body or a river segment. PI-based water quality management can provide stakeholders with an input for considering the use or allocation of a water body and the improvement or reversion of deteriorated water quality due to the presence of toxic elements. PI is comprised of various groups of independent and representative water quality parameters. In this research, PI was determined using the following procedures and requisites:

a. If $\mathrm{L}_{\mathrm{ij}}$ represents the concentration of each water quality parameter cited in the standards of water allocation $(j)$ and $C_{i}$ represents the concentration of water quality parameter (i) obtained from water sample analysis in the predefined locations along a river, then $\mathrm{PI}_{\mathrm{j}}$ is the pollution index for water allocation (j)

$$
P I_{j}=f\left(C_{1} / L_{1 j}, C_{2} / L_{2 j}, \ldots, C_{1} L_{1 j}\right)
$$

b. Every value of $\mathrm{C}_{\mathrm{i}} / \mathrm{L}_{\mathrm{ij}}$ shows a relative pollution caused by the improper concentration of water quality parameter.

c. $\mathrm{C}_{\mathrm{i}} / \mathrm{L}_{\mathrm{ij}}=1$ represents a critical value. This value is expected to be met by the standards of water quality allocation.

d. If a parameter has $\mathrm{C}_{\mathrm{i}} / \mathrm{L}_{\mathrm{ij}}>1$, then the concentration of this parameter has to be reduced or set aside when arelated water body is used for allocation (j). If this parameter is the determinant of a water allocation, then an absolute water treatment has to be performed.

e. The Pollution Index model uses various parameters of water quality, therefore, its application requires the average and maximum values of all $\mathrm{C}_{\mathrm{i}} / \mathrm{L}_{\mathrm{ij}}$

$$
P I_{j}=\left\{\left(C_{1} / L_{1 j}\right)_{R},\left(C_{1} / L_{1 j}\right)_{M}\right\}
$$

where:

$\left(\mathrm{C}_{1} / \mathrm{L}_{1 \mathrm{j}}\right)_{\mathrm{R}}$ is the average value of $\mathrm{C}_{1} / \mathrm{L}_{1 \mathrm{j}}$

$\left(\mathrm{C}_{1} / \mathrm{L}_{1 \mathrm{j}}\right)_{\mathrm{M}}$ is the maximum value of $\mathrm{C}_{1} / \mathrm{L}_{1 \mathrm{j}}$

$m$ is a balance factor evaluated at critical value. When the critical values of $\mathrm{PI}_{\mathrm{j}},\left(\mathrm{C}_{1} / \mathrm{L}_{1 \mathrm{j}}\right)_{\mathrm{R}}$, and $\left(\mathrm{C}_{1} / \mathrm{L}_{1 \mathrm{j}}\right)_{\mathrm{M}}$ are 1 , then the value of $m$ is $1 \sqrt{ } 2$.

Therefore:

$$
\mathrm{PI}_{\mathrm{j}}=\frac{\sqrt{\left(\mathrm{C}_{1} / \mathrm{L}_{1 \mathrm{j}}\right)^{2} \mathrm{M}+\left(\mathrm{C}_{1} / \mathrm{L}_{1 \mathrm{j}}\right)^{2} \mathrm{R}}}{2}
$$

The evaluation of $\mathrm{PI}_{\mathrm{j}}$

$$
\begin{array}{ll}
0 \leq \mathrm{PI}_{\mathrm{j}} \leq 1 & : \text { within the standards } \\
1<\mathrm{PI}_{\mathrm{j}} \leq 5 & : \text { slightly polluted } \\
5<\mathrm{PI}_{\mathrm{j}} \leq 10 & : \text { moderately polluted } \\
\mathrm{PI}_{\mathrm{j}}>10 & : \text { severely polluted }
\end{array}
$$


f. The procedure for using the equation is as follows:
a) Collecting the concentration of pollutant parameter $\left(\mathrm{C}_{\mathrm{i}}\right)$ as the main data in this equation
b) Determining the standards $\left(\mathrm{L}_{\mathrm{ij}}\right)$
c) Calculating $\mathrm{C}_{\mathrm{i}} / \mathrm{L}_{\mathrm{ij}}$
d) Calculating $\left(\mathrm{C}_{1} / \mathrm{L}_{1 \mathrm{j}}\right)_{\mathrm{R}}$ and $\left(\mathrm{C}_{1} / \mathrm{L}_{1 \mathrm{j}}\right)_{\mathrm{M}}$
e) Calculating $\mathrm{PI}_{j}$

\section{RESULTS AND DISCUSSION}

The research included 4 water samples, i.e., 2 samples in the areas outside the city and 2 samples in the areas close to Opak River (the lower stream of Code River).
The water sampling considered the administrative boundary as well as the map of water aquifer in the area. Afterward, the spring water and groundwater samples obtained from the local residential wells in the study area were analyzed immediately in the laboratory of water quality in order to preserve data accuracy. The laboratory analysis included several methods, namely, volumetric, spectrophotometric, and gravimetric methods as well as ion selective-electrodes. The results of the laboratory analysis of groundwater samples in the study are presented in Table 1 .

Table 1.The results of laboratory analysis of groundwater samples in the lower part (downstream) of Code Watershed.

\begin{tabular}{|c|c|c|c|c|c|c|}
\hline \multirow{2}{*}{$\begin{array}{l}\text { Sample Codes } \\
\text { Parameters }\end{array}$} & \multirow[b]{2}{*}{ Units } & DS* I & DS II & DS III & DS IV & \multirow{2}{*}{$\begin{array}{c}\text { Standards of } \\
\text { Class I }\end{array}$} \\
\hline & & & & & & \\
\hline \multicolumn{7}{|l|}{ 1. Physical } \\
\hline Temperature & ${ }^{\circ} \mathrm{C}$ & 26 & 27 & 27.5 & 27.4 & Deviation 3 \\
\hline Turbidity & NTU & 1.21 & 1.30 & 1.23 & 1.49 & 5 \\
\hline TSS & $\mathrm{mg} / \mathrm{L}$ & 0.47 & 0.5 & 0.72 & 0.82 & 0 \\
\hline TDS & $\mathrm{mg} / \mathrm{L}$ & 391 & 397 & 399 & 402 & 1000 \\
\hline $\mathrm{EC}$ & $\mu \mathrm{mhos} / \mathrm{cm}$ & 520 & 529 & 533 & 539 & - \\
\hline \multicolumn{7}{|l|}{ Il. Chemical } \\
\hline $\mathrm{pH}$ & - & 7.00 & 7.01 & 6.82 & 6.97 & $6-8.5$ \\
\hline Nitrite $\left(\mathrm{NO}_{2}{ }^{-}\right)$ & $\mathrm{mg} / \mathrm{L}$ & 0.001 & 0.003 & 0.006 & 0.005 & 0.06 \\
\hline Nitrate $\left(\mathrm{NO}_{3}^{-}\right)$ & $\mathrm{mg} / \mathrm{L}$ & 5.90 & 1.63 & 7.08 & 4.62 & 10 \\
\hline Chloride $\left(\mathrm{Cl}^{-}\right)$ & $\mathrm{mg} / \mathrm{L}$ & 33.49 & 35.47 & 47.29 & 39.41 & 600 \\
\hline Sulfate $\left(\mathrm{SO}_{4}^{-2}\right)$ & $\mathrm{mg} / \mathrm{L}$ & 28.97 & 30.24 & 41.58 & 38.88 & 400 \\
\hline Ammonia $\left(\mathrm{NH}_{4}^{-}\right)$ & $\mathrm{mg} / \mathrm{L}$ & 0.25 & 0.20 & 0.19 & 0.19 & 0.5 \\
\hline Total Iron $(\mathrm{Fe})$ & $\mathrm{mg} / \mathrm{L}$ & 0.21 & 0.14 & 0.14 & 0.13 & 0.3 \\
\hline Dissolved Oxygen (DO) & $\mathrm{mg} / \mathrm{L}$ & 7.80 & 7.82 & 7.81 & 7.80 & 6 \\
\hline BOD & $\mathrm{mg} / \mathrm{L}$ & 1.18 & 1.16 & 0.67 & 0.86 & 2 \\
\hline COD & $\mathrm{mg} / \mathrm{L}$ & 3.67 & 4.54 & 1.92 & 2.41 & 10 \\
\hline \multicolumn{7}{|l|}{ IIl. Microbiological } \\
\hline Total coliform & $\mathrm{MPN} / 100 \mathrm{ml}$ & 1100 & $\geq 2400$ & $\geq 2400$ & 1100 & 1000 \\
\hline
\end{tabular}

Based on the physical, chemical, and biological characteristics presented in Table 1, the groundwater in the study area experienced anelevated concentration of TSS and total coliform. The analysis results showed that the groundwater quality in the study area was Class II.

The high concentration of certain elements in the groundwater was influenced by waste disposal activities, particularly of domestic waste, which would likely result in severely contaminated and undrinkable groundwater when the disposal remained uncontrolled. The analysis results of water samples in the study area, based on the class of the water quality, are presented in Table 2 .

Table 2. Groundwater sample analysis in the study area based on the Governor Regulation No. 20/2008 on the Water Quality Standards in the Special Region of Yogyakarta.

\begin{tabular}{llll}
\hline No & Location Codes & Water Classes & Polluting Parameters \\
\hline 1 & DS I & II & TSS, Total coliform \\
2 & DS II & II & TSS, Total coliform \\
3 & DS III & II & TSS, Total coliform \\
4 & DS IV & II & TSS, Total coliform \\
\hline
\end{tabular}

The status of the environmental quality in the study area is presented in Table 3 .

Table 3. The Pollution Index (PI) of the study area.

\begin{tabular}{llll}
\hline No & Location Codes & Pollution Indices & Pollution Status \\
\hline 1 & DS I & 1.085813 & Slightly Polluted \\
2 & DS II & 1.810719 & Slightly Polluted \\
3 & DS III & 1.858101 & Slightly Polluted \\
4 & DS IV & 1.176268 & Slightly Polluted \\
\hline
\end{tabular}

The areas between Depok (Sleman Regency) and the city were densely populated. The domestic waste disposal into the ground introducedpollutants to the groundwater. In general, the urban areas in the watershed experienced groundwater pollution. The high concentration of nitrate and total coliform was caused by wastes from water retention and toilets. In urban areas, soil surface is mostly covered with cement and asphalt, which reduces the amount of rainwater infiltration significantly. In areas with severe pollution, the lack of 
infiltrated water leads to ineffective pollutant dilution. Therefore, the groundwater in urban areas and the areas downstream is prone to pollution.

In the lower watershed, there are still many open green spaces, which contribute to the intensive infiltration of rainwater into the ground and to the effective dilution of groundwater. The groundwater in the lower Code Watershed was classified as Class II, indicating a slight pollution. The contaminated groundwater was caused by the function of the lower area as the receiver of waste disposal from the city upstream. At the same time, the activities in the lower watershed slightly contributed to the groundwater pollution. The analysis results showed that the groundwater in the lower Code Watershed was categorized as Class II even though there were only two pollutants, namely, TSS and total coliform.

\section{CONCLUSIONS}

1. The groundwater in the lower Code Watershed was polluted by TSS and E. Coli

2. Because the groundwater quality was polluted, it no longer met the quality standard for Class I. It became Class II.

3. The liquid and solid waste treatment systems in the study area did not support environmental sustainability.

\section{REFERENCES}

Karmono and Cahyono. 1978. Pengantar Penentuan Kualitas Air. Serayu Valley Project, NUFFIC-UGM.

Keputusan Menteri Lingkungan Hidup, Nomor KEP115/MENLH/2003.

Purwodarminto.1976.KamusUmumBahasa Indonesia.Penerbit Balai Pustaka, Jakarta. 